\title{
Seismic vulnerability of masonry infilled reinforced concrete frame structures
}

\author{
A. Madan \\ Department of Civil Engineering, Indian Institute of Technology, \\ Hauz Khas, New Delhi, India
}

\begin{abstract}
Despite intense worldwide research in the area of masonry infilled frame structures during the past half a century, displacement-based non-linear analyses of masonry infilled frames with explicit consideration of infill panels as structural elements is far from common practice in earthquake resistant design of such structures. The displacements are of particular interest from the viewpoint of performance-based design (PBD), the emerging paradigm for the next generation of standard codes of practice for earthquake resistant design. The present paper is based on an analytical study of the seismic performance and vulnerability of typical planar masonry infilled reinforced concrete $(\mathrm{R} / \mathrm{C})$ frames considering the effect of distribution of masonry infill panels over the elevation of the $\mathrm{R} / \mathrm{C}$ frame using rational displacement based analysis methods such as non-linear dynamic time-history analysis based on realistic and efficient hysteretic models of the structural elements. The results of the displacementbased analyses are used to develop seismic vulnerability curves in probabilistic terms for the populations of typical medium-rise masonry infilled reinforced concrete $(\mathrm{R} / \mathrm{C})$ framed buildings. The proposed seismic vulnerability curves are termed as fragility curves in the present study that provide useful tools for predicting life and economic losses in the event of a future earthquake.
\end{abstract}

Keywords: seismic vulnerability, seismic demand, fragility analysis, performance based seismic design.

\section{Introduction}

More than 90 percent of multi-story buildings in urban India and, in general, Asia are constructed as reinforced concrete $(\mathrm{R} / \mathrm{C})$ framed structures with 
masonry infills for architectural, aesthetic, functional or economic reasons. There is presently no statistically viable observational database on the post-earthquake seismic damage surveyed by experts in the building structures of India. However, a particular configuration of engineered masonry infilled $\mathrm{R} / \mathrm{C}$ frame structures that was observed to suffer severe damage and in some cases complete collapse in the recent Bhuj earthquake (2001) in Gujarat (India) and the Turkey earthquake (1999) in Adapazari (Turkey) was the one in which the masonry infill panels are discontinued above the base for reasons of functionality to create an open story, commonly known as a 'soft' and / or 'weak' story at the base of the building. In 1897, north-eastern Assam in India experienced an earthquake with epicenter at Shillong (north-east India) measuring 8.6 on the Richter scale, one of the strongest ground shaking measured anywhere in the world. The 'Science' magazine in a recent issue reported that there is a substantial evidence to show that one or more of such great earthquakes may be overdue in the Himalayan arc threatening millions of people, many of them in the cities, towns and villages of the Indo-Gangetic plains of north and central India [1].

Vulnerability curves for civil engineering structures play an important role in regional seismic hazard and loss assessment, which are essential for purposes of disaster preparedness and response planning [2]. In the case of building populations, the seismic vulnerability curves enable a prediction of the proportion of the exposed building stock in each damage state in the event of an earthquake of given severity of ground shaking. Seismic vulnerability curves may be defined as functions that relate the probability of exceedance of multiple performance limit states of a structure to a parameter of the severity of the earthquake. The vulnerability curves may thus be viewed as a graphical representation of seismic risk. The performance limit state may be quantified by the maximum inter-story drift, the top displacement of the structure or a related damage grade of the structure. The number of limit states used generally varies from three to five [3]. The three performance limit states that are considered most important are immediate occupancy (IO), life safety (LS) and collapse prevention (CP). The severity of the earthquake ground shaking may be represented by spectral ordinates such as the spectral displacement $\left(\mathrm{S}_{\mathrm{d}}\right)$, velocity $\left(\mathrm{S}_{\mathrm{v}}\right)$ or acceleration $\left(\mathrm{S}_{\mathrm{a}}\right)$ or ground motion intensity (I) or simply the peak ground acceleration (pga) of the earthquake. There is no unique methodology for development of vulnerability curves as the methodology differs depending on the choice of analytical modelling, damage model and seismic hazard [3].

Mosalam et al. [4] presented a comprehensive review of the literature published till 1997 on the analytical modelling and experimental testing of masonry infilled reinforced concrete $(\mathrm{R} / \mathrm{C})$ framed structures for evaluating the seismic performance and fragility of such structures. An additional review of the literature published subsequently indicates that a limited number of research studies have been reported in the past on the seismic risk assessment of reinforced concrete frames with explicit consideration of the masonry infill panels as structural elements. Rossetto and Elnashai [2] developed probabilistic vulnerability functions termed as fragility functions for typical European $\mathrm{R} / \mathrm{C}$ buildings based on observational damage data. New empirical fragility curves 
are derived for a population of $\mathrm{R} / \mathrm{C}$ buildings of typical European or similar construction based on a data bank of 99 post-earthquake damage distributions observed in 19 earthquakes for a total of 3,40,000 R/C structures. Mosalam et al. [4] analytically obtained probabilistic vulnerability curves termed as fragility curves for low-rise lightly reinforced concrete (LRC) framed structures with and without infills, a generic class of buildings in the region of Memphis, USA. One of the conclusions of the study by Mosalam et al. [4] was that adding masonry infill walls to low-rise LRC frame buildings significantly reduces the probability of seismic damage. However, the study focussed on low-rise (two story R/C frames). Dumova-Jovanoska [5] proposed an analytical method for development of fragility curves for medium-rise reinforced concrete $(\mathrm{R} / \mathrm{C})$ frame - wall structures designed according to the Macedonian seismic design code considering the local seismic hazard of the Skopje region in Macedonia. The seismic performance of the two sample $\mathrm{R} / \mathrm{C}$ frames (six and sixteen stories respectively) were evaluated by performing non-linear dynamic analyses under synthetic earthquake ground motions using the modified Park and Ang damage model [6] for quantification of seismic damage.

More recently, Rossetto and Elnashai [7] also proposed an analytical procedure based on the capacity spectrum method for deriving the displacement based probabilistic vulnerability curves for seismic assessment of a population of reinforced concrete $(\mathrm{R} / \mathrm{C})$ frames. The proposed methodology is employed for generating the vulnerability curves for low-rise infilled $\mathrm{R} / \mathrm{C}$ frames with inadequate seismic provisions [7]. Kircil and Polat [8] developed fragility curves for mid-rise $\mathrm{R} / \mathrm{C}$ framed building stock in Istanbul using incremental dynamic analyses of sample buildings subjected to twelve artificial ground motions However, none of the research studies cited above consider the effect of the distribution of masonry infill panels over the frame elevation on the seismic vulnerability of the $\mathrm{R} / \mathrm{C}$ frame. Madan and Hashmi [9] reported a detailed review of literature on performance based seismic engineering of masonry infilled frames published since 1997. An important objective of the present study is to develop seismic vulnerability curves for representative configurations of medium-rise masonry infilled $\mathrm{R} / \mathrm{C}$ frame structures considering the effect of distribution of masonry infill panels over the frame elevation on seismic performance of the $\mathrm{R} / \mathrm{C}$ frame.

\section{Seismic vulnerability assessment of masonry infilled r/c framed building structures}

The present study is based on the analytical development of seismic vulnerability curves for practical multi-story masonry infilled $\mathrm{R} / \mathrm{C}$ frame structures with the commonly implemented seismically undesirable as well as preferred distributions of the masonry infill panels over the frame elevation using rational displacement-based analysis techniques within the performance-based framework. Based on a review of architectural plans and structural framing schemes of masonry infilled $\mathrm{R} / \mathrm{C}$ framed buildings constructed in practice, some representative planar masonry infilled $\mathrm{R} / \mathrm{C}$ frame configurations were identified 
for the analytical investigation of seismic performance and vulnerability of the building stock of interest. The analytical investigation was performed for the following six multi-bay multi-story geometries of planar $\mathrm{R} / \mathrm{C}$ frames with a different number of bays and / or different bay lengths:

(1) Fourteen storys three bay frame with a bay length of 3.0 meters,

(2) Fourteen storys three bay frame with a bay length of 6.0 meters,

(3) Fourteen storys five bay frame with a bay length of 3.0 meters,

(4) Fourteen storys five bay frame with a bay length of 6.0 meters,

(5) Seven storys three bay frame with a bay length of 3.0 meters,

(6) Seven storys five bay frame with a bay length of 3.0 meters.

The following practically relevant cases of distribution of masonry infill panels along the elevation of a planar masonry infilled $\mathrm{R} / \mathrm{C}$ frame were identified for the analytical evaluation:

a) Completely infilled frame [Figure 1 (a)],

b) Infilled frame without infill panels in the first (ground) story ('soft / weak story' at ground level) [Figure 1 (b)],

c) Infilled frame with partially infilled first (ground) story ('soft / weak story' at the ground level with some panels infilled with masonry) [Figure 1 (c)],

d) Bare Frame [Figure $1(\mathrm{~d})]$.

The masonry infilled R/C framed building structures with the representative configurations were designed in accordance with the current Indian Standard (IS) code of practice for earthquake resistant design IS: 1893-2002 [10] (Indian seismic design code) using the computer program STAAD Pro, a popular software for structural analysis and design in the construction industry that is now integrated with the Bentley software systems for infrastructure design. It may be noted that the format and model of the latest revision of Indian seismic design code [10] as well as the underlying seismic design philosophy are similar to those of the Uniform Building Code (now IBC) of America [11]. Figure 2 shows a typical multi-bay multi-story masonry infilled planar $\mathrm{R} / \mathrm{C}$ frame in a representative masonry infilled $\mathrm{R} / \mathrm{C}$ framed building structure with 14 storeys and five bays in the weak direction designed in accordance with the current Indian seismic design code. The figure also presents the material properties assumed in the design of the 14 storys building with five bays in the weak direction. The typical design dimensions and reinforcement details for different structural frame members are also summarized in Figure 2.

\subsection{Seismic fragility curves for generic population of masonry infilled r/c framed buildings}

The seismic performance and vulnerability of masonry infilled R/C framed building structures is assessed by performing non-linear dynamic analysis of the representative planar masonry infilled $\mathrm{R} / \mathrm{C}$ frame configurations identified in the previous section of the paper under the action of twenty artificially generated 


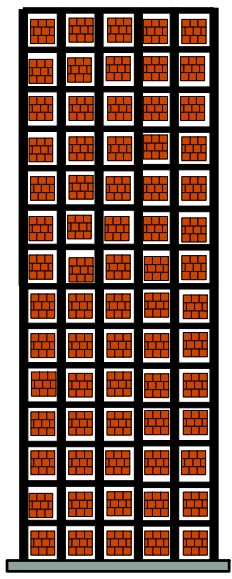

(a) Completely Infilled Frame

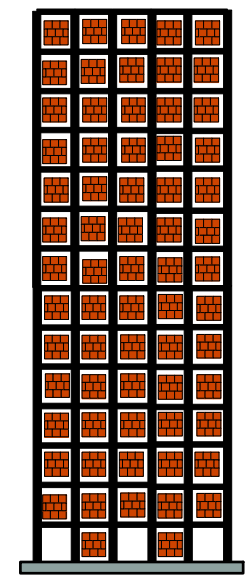

(c) Infilled Frame with Partially Infilled First (Ground) Story

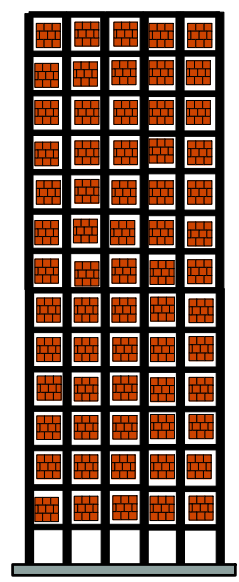

(b) Infilled Frame without any Infill Panels in First Story ('Soft' Ground Story)

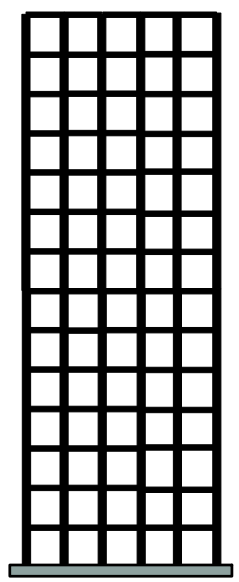

(d) Bare Frame

Figure 1: Practically relevant distributions of masonry infill panels over the elevation of a planar masonry-infilled reinforced concrete $(\mathrm{R} / \mathrm{C})$ frame with frame geometry 3 . 


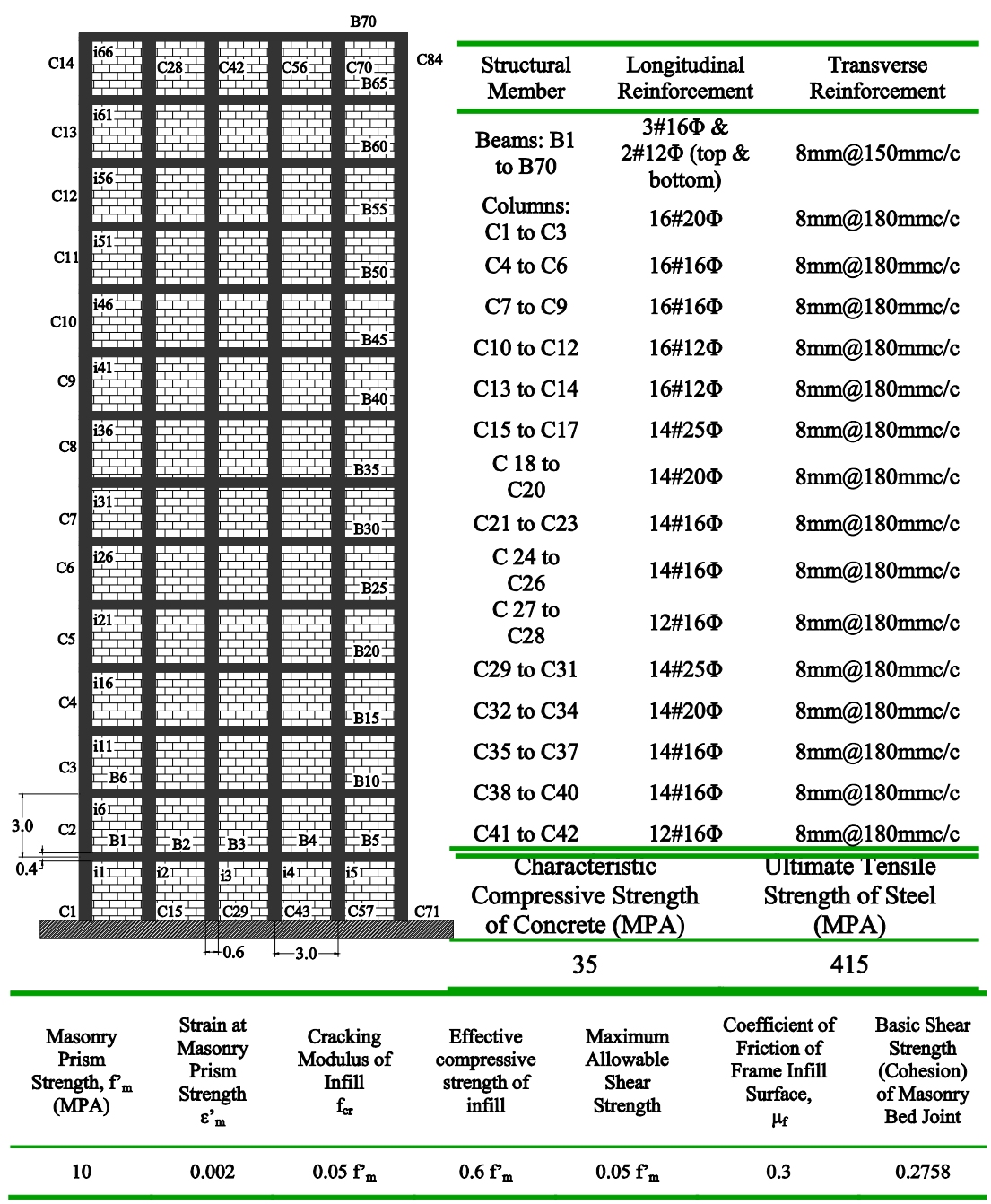

Figure 2: $\quad$ Typical multi-bay multi-story planar masonry-infilled $\mathrm{R} / \mathrm{C}$ frame with frame geometry 3 in elevation with design details and material properties.

earthquake ground motions that are compatible with the design response spectrum specified by the seismic design code for the region [10]. The synthetic earthquake ground motions were generated for ascending peak ground accelerations in the range of $0.1 \mathrm{~g}$ to $2.0 \mathrm{~g}$. The non-linear dynamic analysis of the masonry infilled $\mathrm{R} / \mathrm{C}$ frame was performed in the present study using rational 
and realistic hysteretic models of the structural elements including masonry infill panels $[6,12]$. Seismic fragility functions relate the probability of exceedance of multiple performance limit states to a parameter of severity of the earthquake. Fragility curves thus provide a graphical representation of the seismic vulnerability of the building structure in statistical terms. The vertical distance between two adjacent fragility curves represents the probability of the structure being within lower of the two performance limit states under consideration following the design seismic event. Further, a steep rise in the fragility curve implies that the seismic vulnerability of the structure is highly sensitive to changes in the seismic demand. On the other hand, a more level or flat rise in the fragility curve represents superior seismic performance.

Seismic fragility curves were developed in the present study for the representative configurations of practical medium rise masonry infilled multistory $\mathrm{R} / \mathrm{C}$ framed structures identified in a previous section of the paper for the three important structural performance limit states of immediate occupancy, life safety and collapse prevention. The performance limit states are quantified in terms of the maximum inter-story drift using the global acceptance criteria of $1 \%, 2 \%$ and $4 \%$ inter-story drifts specified by ATC-40 [13] and FEMA-356 [14] for defining the immediate occupancy (IO), life safety (LS) and collapse prevention $(\mathrm{CP})$ performance levels for $\mathrm{R} / \mathrm{C}$ framed structures respectively. The seismic fragility function adopted for medium-rise masonry infilled $\mathrm{R} / \mathrm{C}$ framed buildings in the present may be described by the following probability equation proposed by Wen et al. [15]. Details of formulation and variables of the probability equation may be found else where [15].

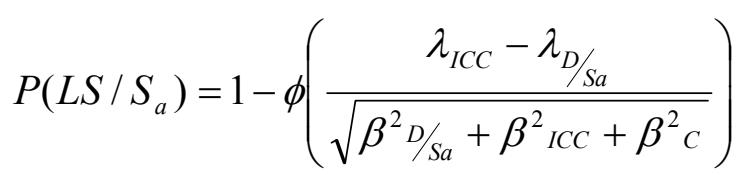

where, $\quad P\left(L S / S_{a}\right)=$ Probability of exceeding a limit state LS given the spectral acceleration corresponding to the fundamental period of the building and $\phi$ is the standard normal distribution function.

Figures 3 (a) and (b), respectively, display the seismic fragility curves obtained for the code-compliant masonry infilled planar $\mathrm{R} / \mathrm{C}$ frame that is completely infilled and the seismic fragility curves for the corresponding masonry infilled frame without any infills in the first (ground) story (i.e. with a 'soft' story at the ground level). Each figure illustrates the fragility curves for the three important performance limit states of immediate occupancy (IO), life safety (LS) and collapse prevention (CP) limit states of the code-compliant $\mathrm{R} / \mathrm{C}$ frame for all the six representative planar frame geometries identified in a previous section of the paper. A brief inspection of Figures 3 (a) and (b) reveals that the probability of exceeding any limit state (IO, LS or CP) rises more steeply with increase in the spectral acceleration for the masonry infilled $\mathrm{R} / \mathrm{C}$ frame with a soft story at the ground level for all frame geometries in comparison to the 

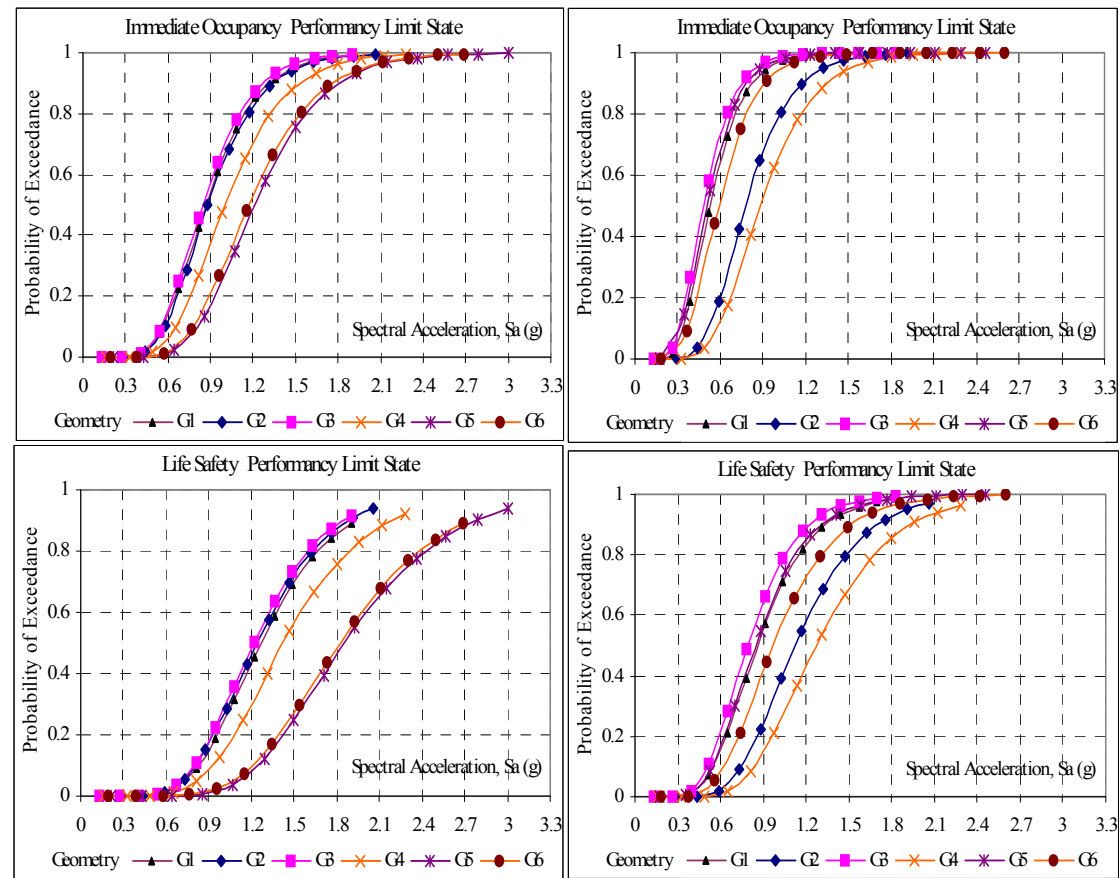

Ceometry $\longrightarrow \mathrm{Gl} \longrightarrow \mathrm{G} \rightarrow-\mathrm{G} \rightarrow \mathrm{GH} \rightarrow \mathrm{G} \rightarrow-\mathrm{C6}$
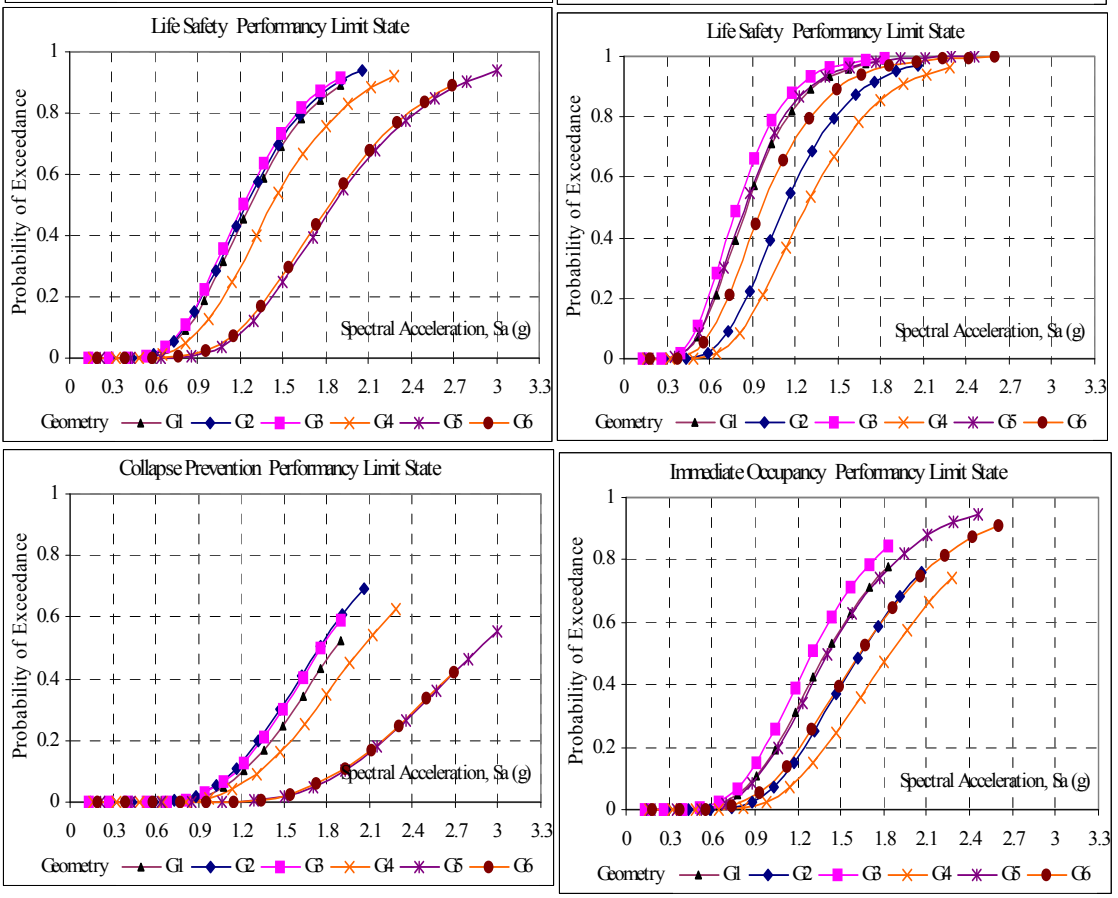

(a) Completely Infilled Frame

(b) Infilled Frame without any Infill Panels in First Story ('Soft' Ground Story)

Figure 3: Seismic fragility curves for code-compliant masonry infilled reinforced concrete frames with frame geometries 1 to 6 for immediate occupancy, life safety and collapse prevention performance limit states.

completely infilled R/C frame. Further, it can be observed from Figure 3 that the ascending segments of the fragility curves are the steepest for frame geometries 3 and 6, generally in that order, while they are the least steep for frame geometries 2 and 4, irrespective of the distribution of the masonry infill panels over the 
frame elevation, thus suggesting that the frame geometries 3 and 6 are seismically most vulnerable. The following section of the paper presents the interpretations of results of fragility analysis of the planar masonry infilled $\mathrm{R} / \mathrm{C}$ frames. For sake of brevity, the results for the two most vulnerable frame geometries 3 and 6 among the six representative planar frame geometries are only discussed.

\subsection{Interpretations of results of fragility analysis}

Figures 4 (i) and (ii) illustrate the seismic fragility curves for frame geometries 3 and 6 , respectively, for the three important limit states of immediate occupancy (IO), life safety (LS) and collapse prevention (CP). Both the figures displays the variation of the probability of exceeding the three performance limit states with respect to the spectral acceleration for the different practically relevant distributions (a), (b), (c) and (d) of masonry infill panels over the frame elevation that are considered in the present study [Figure 1]. The comparison of the fragility curves for the various practically relevant distributions of masonry infill panels over the frame elevation for frame geometries 3 and 6 presented in Figure 4 clearly shows that the fragility of a code-compliant $\mathrm{R} / \mathrm{C}$ frame that is completely infilled with masonry panels is consistently and substantially lower than any other case. In fact, for both frame geometries, the different distributions of masonry infill panels over the frame elevation considered in the present study may be ranked in the decreasing order of fragility as: masonry infilled frame with soft ground story $>$ masonry infilled frame with partially infilled ground story $>$ completely infilled frame. The fragility of the bare frame is, in general, observed to lie between that of the masonry infilled frame with a soft ground and the masonry infilled frame with partially infilled ground story. This implies that a code compliant masonry infilled $\mathrm{R} / \mathrm{C}$ frame that is completely infilled with masonry panels is seismically much less vulnerable than a corresponding bare frame without any infill panels.

\section{Concluding remarks}

The study focuses on the development of region-specific seismic vulnerability curves for typical configurations of practical medium rise masonry infilled multistory $\mathrm{R} / \mathrm{C}$ framed structures for the three important structural performance limit states of immediate occupancy, life safety and collapse prevention as defined by the global acceptance criteria specified by FEMA. The seismic performance and vulnerability of masonry infilled $\mathrm{R} / \mathrm{C}$ framed building structures is assessed through non-linear dynamic analysis of representative planar masonry infilled $\mathrm{R} / \mathrm{C}$ frame geometries subjected to artificially generated earthquake ground motions that are compatible with the design response spectrum specified by the seismic code for the region considering the various commonly implemented distributions of masonry infill panels over the frame elevation. The results of the present study establish that the seismic vulnerability of masonry infilled $\mathrm{R} / \mathrm{C}$ frames is significantly influenced by the density and distribution of the masonry 

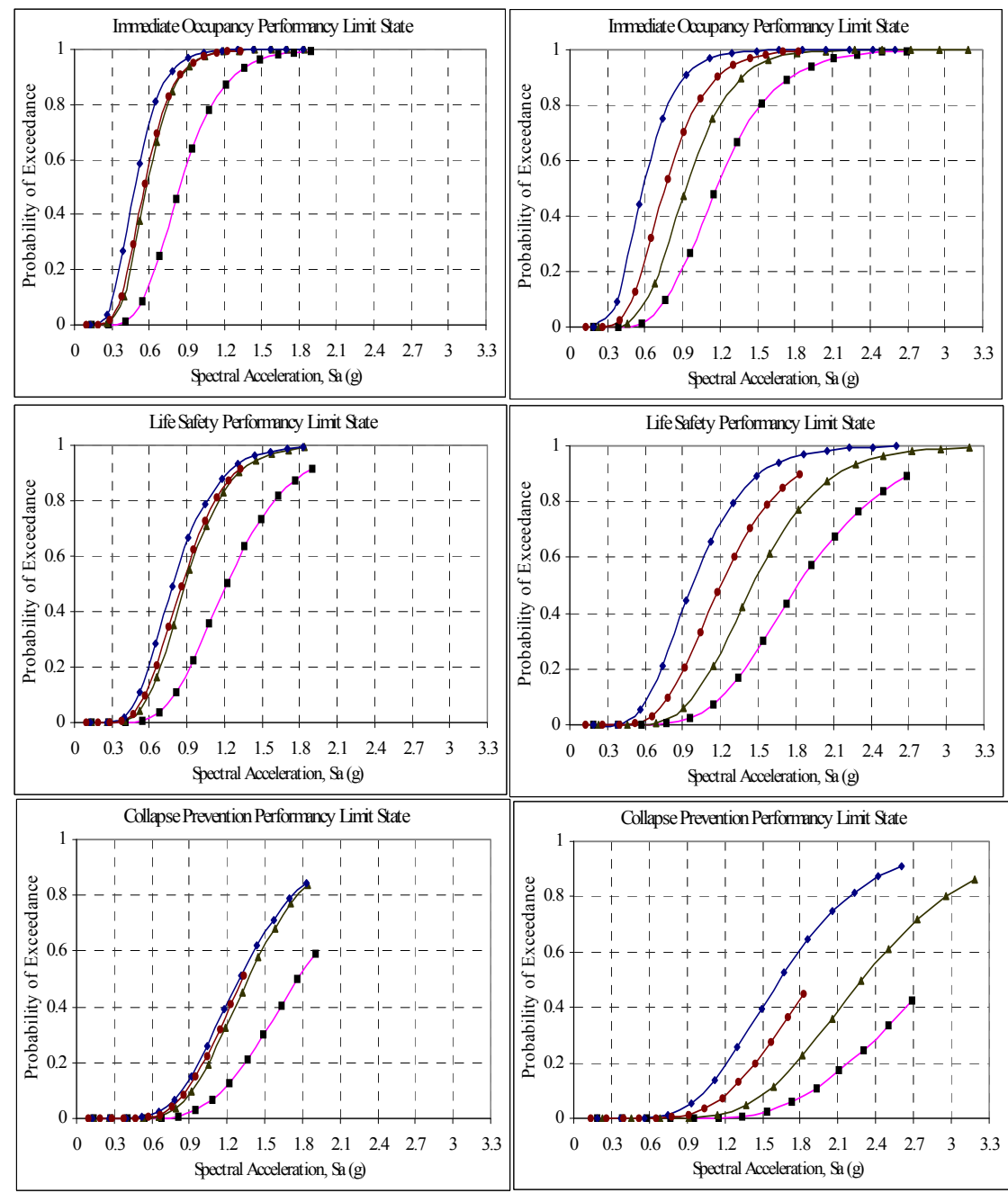

Completely Infilled Frame
Infilled Frame without any Infill Panels in First Story

(i) Frame Geometry 3

$\begin{array}{ll}\text { Infilled Frame with } & \text { Bare } \\ \text { Partially Infilled } & \text { Frame } \\ \text { First Story } & \end{array}$

First Story

(ii) Frame Geometry 6

Figure 4: Seismic fragility curves for masonry infilled R/C frame with different practically relevant distributions of masonry infill panels over frame elevation for frame geometries 3 and 6 (G3 and G6).

infill panels in the $\mathrm{R} / \mathrm{C}$ frame, an effect that is disregarded by the present generation of the seismic codes. 
It can be concluded from the interpretation of the seismic vulnerability curves that the presence of masonry infills in a $\mathrm{R} / \mathrm{C}$ frame substantially reduces the probability of seismic damage in the frame members provided the frame does not have a soft ground story due to abrupt interruption or reduction of infill panels at the ground level. However, the fragility of a masonry infilled R/C frame is considerably intensified by the 'soft' story effect at the ground level due to discontinuation of masonry infills at the ground story. The fragility is considerably mitigated if the soft story effect at the ground story is sufficiently compensated by partially infilling the soft ground story with masonry panels or designing the columns in the soft story to resist the surplus base shear due to the masonry infills. The fragility functions are developed in the present study using rational displacement-based analysis techniques within the performance-based framework. The resulting fragility curves provide important prediction tools that allow the seismic risk assessment and loss estimation within a performancebased framework for the extensive newly built environment in the proximity of the highly populated metropolises. Such loss estimations are necessary for the formulation of disaster management policies in the region as well as implementation of disaster intervention strategies such as aseismic retrofitting

\section{References}

[1] Bilham, R., Gaur, V. K., and P. Molnar, P. Himalayan Seismic Hazard. Science 2001; 293(5534), 1442-1444.

[2] Rossetto T. and Elnashai A. Derivation of Vulnerability Function for European- Type RC Structures Based on Observational Data. Engineering Structures 2003; 25(10), 1241-1263.

[3] Kwon, O.S., and Elnashai A. The Effect of Material and Ground Motion Uncertainty on the Seismic Vulnerability Curves of RC Structures. Engineering Structures 2006; 28(2), 289-303.

[4] Mosalam KM, Ayala G, White RN and Roth C. Seismic Fragility of LRC Frames With and Without Masonry Infill Walls. Journal of Earthquake Engineering 1997;1; 693-720

[5] Dumova-Jovanoska E. Fragility Curves for Reinforced Concrete Structures in Skopje (Macedonia) Region. Soil dynamics and earthquake engineering 2000; 19; 455-66

[6] Valles RE, Reinhorn AM, Kunnath SK, Li C and Madan, A. IDARC Version 4.0 - A Program for the Inelastic Damage Analysis of Buildings. Technical Report NCEER-96-0010, National Center for Earthquake Engineering Research, SUNY/Buffalo 1996.

[7] Rossetto T. and Elnashai A. A New Analytical Procedure for the Derivation of Displacement Based Vulnerability Curves for Population of RC Structures. Engineering Structures 2005; 27(3), 397-409

[8] Kircil MS and Polat Z. Fragility Analysis of Mid-Rise RC Frame Buildings. Engineering Structures 2006; 28; 1335-45. 
[9] Madan, A and Hashmi A.K. Analytical prediction of Seismic Performance of Masonry Infilled Reinforced Concrete Frames Subjected to Near-Field Earthquakes. Journal of Structural Engrg, ASCE 2008; 134 (9); 1569-1581.

[10] BIS (2002).."IS 1893-2002 (Part 1): Indian Standard Criteria for Earthquake Resistant Design of Structures, Part 1-General Provisions and Buildings.” Bureau of Indian Standards, New Delhi, India.

[11] ICC IBC 2000, "2000 International Building code", International Code Council, Washington D.C.

[12] Madan A, Reinhorn AM, Mander JB, Valles R. Modeling of Masonry Infill Panels for Structural Analysis. Journal of Structural Engineering 1997; 123; $1295-1302$.

[13] ATC-40 Seismic Evaluation and Retrofit of Concrete Buildings. Report SSC 96-01, California Seismic Safety Commission, Applied Technology Council, Redwood, CA 1996.

[14] FEMA-356 .Prestandard and Commentary for Seismic Rehabilitation of Buildings. Federal Emergency Management Agency (FEMA), Washington D. C., USA 2000.

[15] Wen YK, Ellingwood BR and Bracci J. Vulnerability Function Framework for Consequence-Based Engineering. Mid-America Earthquake Center Project, Report, University of Illinois at Urbana-Champaign, Urbana 2004. 